\author{
Marina KIRICHENKO-BABKO ${ }^{1 *}$, Grzegorz ŁAGÓD², Dariusz MAJEREK ${ }^{3}$ \\ Małgorzata FRANUS ${ }^{4}$ and Roman $\mathrm{BABKO}^{1}$
}

\title{
THE EFFECT OF LANDSCAPE ON THE DIVERSITY IN URBAN GREEN AREAS
}

\author{
ODDZIAŁYWANIE KRAJOBRAZU NA RÓŻNORODNOŚĆ \\ W OBSZARACH ZIELENI MIEJSKIEJ
}

\begin{abstract}
This article presented the results of a comparative analysis of carabid species compositions (Coleoptera: Carabidae) in urban green areas of the City of Lublin, Eastern Poland. In this study, the occurrence and abundance of ground beetles were analysed according to habitat preference and dispersal ability. A total of 65 carabid species were found in the three green areas. Obviously, the high species richness of ground beetles in the greenery of the Lublin is determined by the mostly undeveloped floodplain of the river Bystrzyca. The species richness of carabids and their relative abundance decrease in the assemblage of green areas under the effect of isolation of green patches and fragmentation of the semi-natural landscape elements in the urban environment. Generalists and open-habitat species significantly prevailed in all green areas. The prevailing of riparian and forest species at floodplain sites of the river Bystrzyca demonstrated the existence of a connection of the carabid assemblage with landscape of river valley. The Saski Park and gully "Rury" are more influenced by urbanization (fragmentation, isolation of green patches) and recreation that is consistent with the significant prevalence of open-habitats species in the carabid beetle assemblage.
\end{abstract}

Keywords: green areas, Carabidae, species diversity, urban ecology, Poland

\section{Introduction}

The growth of populated areas and the transformation of landscapes have been important factors from the second half of the $20^{\text {th }}$ century to the present. The expansion of cities is accompanied by reduced ratio of green to residential zones. Urban ecosystems are characterized by high-density human habitation, intense transportation processes, and only remnants of natural habitats $[1,2]$. At the same time, permanent contamination is experienced in the territory of modern settlements through atmospheric precipitation and

\footnotetext{
${ }^{1}$ Schmalhausen Institute of Zoology NAS of Ukraine, B. Khmelnitsky 15, Kiev, 01030, Ukraine

${ }^{2}$ Faculty of Environmental Engineering, Lublin University of Technology, ul. Nadbystrzycka 40B, 20-618 Lublin, Poland

${ }^{3}$ Faculty of Fundamentals of Technology, Lublin University of Technology, ul. Nadbystrzycka 38, 20-618 Lublin, Poland

${ }^{4}$ Faculty of Civil Engineering and Architecture, Lublin University of Technology, ul. Nadbystrzycka 40, 20-618 Lublin, Poland

*Corresponding author: kirichenko@izan.kiev.ua
} 
dust settling [3, 4]. Pollutants can be influence invertebrates [5]. As noted McIntyre et al. [6] the invertebrate diversity decreases with increasing level of pollution. The considerable isolation of urban green areas (parks, squares, flowerbeds, grass spots and water bodies) from the ecosystems surrounding the cities leads to a decrease in biological diversity $[7,8]$. According to the modern trends, the majority of the townspeople become isolated from the nature. The citizen's isolation from nature in megalopolises is accompanied by psychological discomfort [9]. Thus, nowadays the importance of green areas as location for recreational activities is obvious. Currently, projects are aimed at combining the residential areas with green planting to a greater extent. However, this task can be fulfilled in two ways: by construction of artificial green zones instead of natural ones or by conservation of native landscape fragments amidst the buildings.

A study of the arthropod assemblage structure may provide more general insights into the phenomenon of urbanization [1]. Several papers concerning this aspect have been published, dealing with the diversity of ground beetles in urban landscapes [10-18]. The majority of research is focused on the study of woodlands in cities (parks, remains of natural forests) [19-21], and very rarely - open habitats - such as meadows or grasslands $[22,23]$.

In this article, the results of a comparative analysis of the structure of ground beetle assemblages and species richness in the green areas of the Lublin are presented; the well-known approach of urban-rural gradient has not been adopted. The questions discussed in this paper are: (1) whether the landscape elements determines the species composition of ground beetles assemblages and species richness in urban green areas; (2) what are the differences in the structure of ground beetles assemblages between the studied green areas (based on the habitat affinity of carabid species and their dispersal ability).

\section{Materials and methods}

\section{Study area and sampling}

Our investigations were carried out in different green areas located within the city of Lublin (Eastern Poland) (Fig. 1). These urban green areas are located in the three administrative (historic) parts of this city - Downtown; gully "Rury" and "Za Cukrownia". One area was located in Saski Park (Downtown); this is an old park in Lublin which was founded in 1837. The second green area located among housing estates ("Rury", along T. Zana Street) is undeveloped, overgrown with trees and grass. The third green area includes the different sites along Bystrzyca riverside (outskirts of Lublin University of Technology); it is located on the section of floodplain between the Public Park and Riding Club of Lublin. Saski and Public parks belong to cultural habitats and are visited by many people. All studied territories are under considerable human impact.

In total, 17 sites of the above-mentioned green areas were investigated and their description is given in Table 1 . Ground beetles were collected using pitfall traps. In each study site pitfall traps were emptied every day [24]. Carabid data were pooled at each site per visit. The study was conducted during the vegetation period prior to the reconstruction in the Saski Park and the construction of the stadium "Arena Lublin" in the Bystrzyca floodplain. 


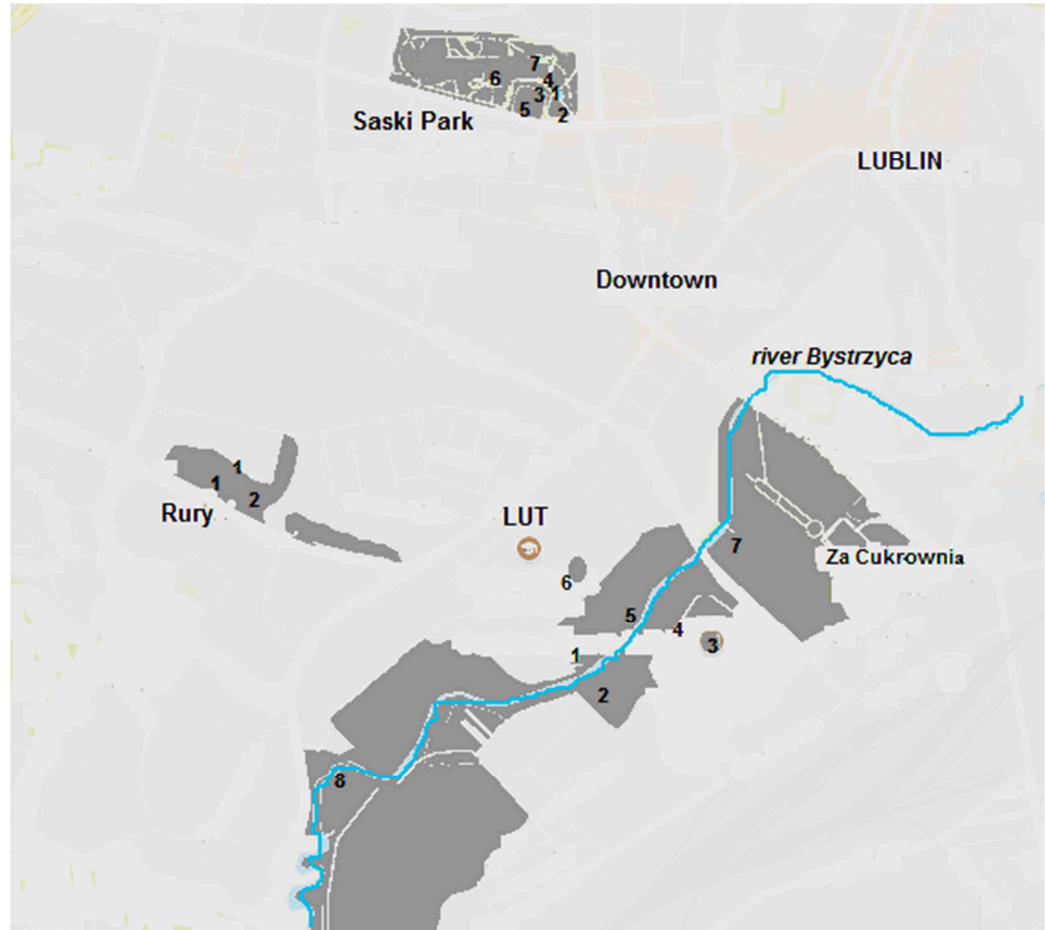

Fig. 1. Location of the sampled green areas in the city of Lublin. Light grey: built-up area; dark-grey: green areas. The numbers correspond to the studying sites for each green area and their description is presented in Table 1. Abbreviation: LUT - Lublin University of Technology

Table 1

List of the studied sites with their general characteristics and mean/total number of carabid species per site

\begin{tabular}{|c|c|c|c|}
\hline $\begin{array}{c}\text { Urban green } \\
\text { area }\end{array}$ & $\begin{array}{l}\text { Code of } \\
\text { site }\end{array}$ & Description habitat & $\begin{array}{c}\text { Number of } \\
\text { species } \\
\text { (mean / total) }\end{array}$ \\
\hline \multirow{8}{*}{$\begin{array}{l}\text { Floodplain of the } \\
\text { Bystrzyca river }\end{array}$} & B1 & Floodplain meadows (left bank) & $3.9 / 16$ \\
\hline & $\mathrm{B} 2$ & Floodplain meadows (right bank) & $3.2 / 13$ \\
\hline & B3 & Small floodplain lake (70 $\mathrm{m}$ from the riverbank) & $12.2 / 28$ \\
\hline & B4 & Floodplain meadows (30 m from the riverbank) & $7.7 / 12$ \\
\hline & B5 & Grass-plat along road & $1.2 / 3$ \\
\hline & B6 & Shore of the small floodplain lake & $4 / 10$ \\
\hline & B7 & Floodplain forest (public park) & $3.5 / 19$ \\
\hline & B8 & Floodplain forest (right bank) & $3 / 2$ \\
\hline \multirow{7}{*}{ Saski Park } & S1 & Stream of bank (right bank) & $4.2 / 10$ \\
\hline & S2 & Stream of bank (left bank) & $4.7 / 10$ \\
\hline & S3 & Lawn with shrubs & $3.5 / 9$ \\
\hline & S4 & Lawn with shrubs & $3.2 / 10$ \\
\hline & S5 & Shrubs & $2.2 / 11$ \\
\hline & S6 & Grass-plot & $1.3 / 4$ \\
\hline & S7 & Shrubs and trees & $2.8 / 9$ \\
\hline \multirow{2}{*}{ Gully "Rury" } & H1 & Shrubs on the ravine slopes & $3.2 / 12$ \\
\hline & $\mathrm{H} 2$ & Bottom of the ravine with herbaceous vegetation & $2.8 / 10$ \\
\hline
\end{tabular}


Ground beetles (Carabidae: Coleoptera) were identified to species level using key [25]. Nomenclature follows Hurka [25]. The habitat preferences and the dispersal capabilities of carabid species were obtained from the literature [26-29]. According to their habitat preferences, ground beetle species were categorized into forest species, generalists, open-habitats species, riparian and tyrphobiont species. In order to better assess the disturbance level of the green areas, we considered the dispersal capabilities of carabids. According to the wing development carabid species were classified into: brachypterous species which disperse solely by walking; macropterous species which mainly disperse by flight and dimorphic species containing both macropterous and brachypterous individuals.

\section{Statistical analysis}

Average density of carabid beetles (number of individuals per trap and day) was used in analysis. In order to conduct the statistical analyses, specimens trapped in pitfalls were pooled per site per green area. The species traits were presented as proportions of the total of carabid species and individuals found in each green area.

Rarefaction was used to estimate the species richness at the different green areas. The analysis of rarefaction gives an estimation of the expected number of species while taking into account the sampling effort and total number of catches [30]. The beta-diversity indices by Cody and Whittaker were used to assess the habitats diversity of the studied urban areas. The differences in the species composition and abundances between sites were examined by means of hierarchical cluster analysis, using group-average linking based on the Bray Curtis similarity matrix. Moreover, Sorensen index of similarity based on the qualitative data was calculated. The differences in carabid assemblage composition between the studied urban green areas were visualised using non-metric multidimensional scaling (NMS) ordination. Non-metric scaling is a non-parametric ordination technique that performs well with datasets, where the underlying species response patterns cannot be specified a priori [31]. Bray-Curtis distance was used for this analysis, and significance of ordination axis was evaluated. Calculations were performed using the PRIMER v6 [32] and Diversity 3.0 software packages.

\section{Results and discussion}

A total of 862 individuals belonging to 65 species were caught, 54 of which occurred in sites of Bystrzyca riverside, 21 species in the Saski Park and 15 species in the gully "Rury" (Table 2). 36 species from 16 genera were registered exclusively in the floodplain of Bystrzyca, six species from 5 genera were found only in the Saski Park, and three species were detected exclusively in the gully "Rury". In all the studied green areas of Lublin, 18 generalist species, 17 open-habitat species, 15 riparian, 13 forest species and 2 tyrphobionts were recorded (Table 2). In addition, four species listed as being under national conservation in the Poland red data book [33] were found - Carabus granulatus, C. nemoralis, Badister dorsiger and Oodes helopioides and other red list of European countries [34, 35].

The observed species richness is high for the urbanized territory. This observation is confirmed by comparison with data for other European cities. For example, Zelazna and Blazejewicz-Zawadzinska [20] conducted a research in six urban green areas of the Bydgoszcz (Poland) in 2000-2003 and 87 carabid species found. In 12 semi-natural grassland sites in the greater Helsinki region, a total of 78 carabid species were caught [23]. 
A total of 99 carabid species were collected in ten different forest fragments, situated around the capital Brussels in Belgium [36]. 70 species were collected in three forests of the Olsztyn (Poland) during one year [37]. According to Tóthmérész et al. [38], 50 species were found in forests nearby the city of Sfantu Gheorghe along rural-urban gradient (Romania). Over the past 20 years in six Swiss cities the 91 ground beetles species were recorded on green roofs [39]. In three woodlands in the City of Debrecen (Hungary) 50 species of carabid beetles were registered [40].

Overall, the most abundant species in the study areas were Nebria brevicollis (22\% of the total catch), Platynus assimilis (15\%), Harpalus latus (7\%) and Leistus rufomarginatus (6.6\%). Of these, the three species $N$. brevicollis, P. assimilis and L. rufomarginatus were abundant in the Saski Park, but H. latus was abundant in the gully "Rury". Similar results were observed by Kosewska et al. [37]: Nebria brevicollis and Platynus assimilis were abundant carabid assemblage from the parks of Olsztyn. The most numerous species in green zones of the Bydgoszcz were such species as Calathus erratus erratus, Calathus fuscipes, Pterostichus oblongopunctatus and Harpalus tardus [19, 20].

Because the territory of the Lublin and the studied green areas are located in the northern part of Lublin upland (landscape between three river valleys - Bystrzyca river and its tributaries Czernejowka and Czechowka), we hypothesized that they were very similar in terms of the species composition and the species richness. Rarefaction curves for species in the Saski Park and in the floodplain section of the Bystrzyca river began to level off only at the maximum sub-sample sizes (number of individuals) (Fig. 2). The green area of the gully "Rury" has the lowest species richness of carabids, due to the vicinity of a residential neighbourhood and increased mowing in park. The rarefied species richness was higher in the Bystrzyca riversides. Therefore, the green areas of the Lublin are distinguished by their potential in maintaining a species diversity of ground beetles.

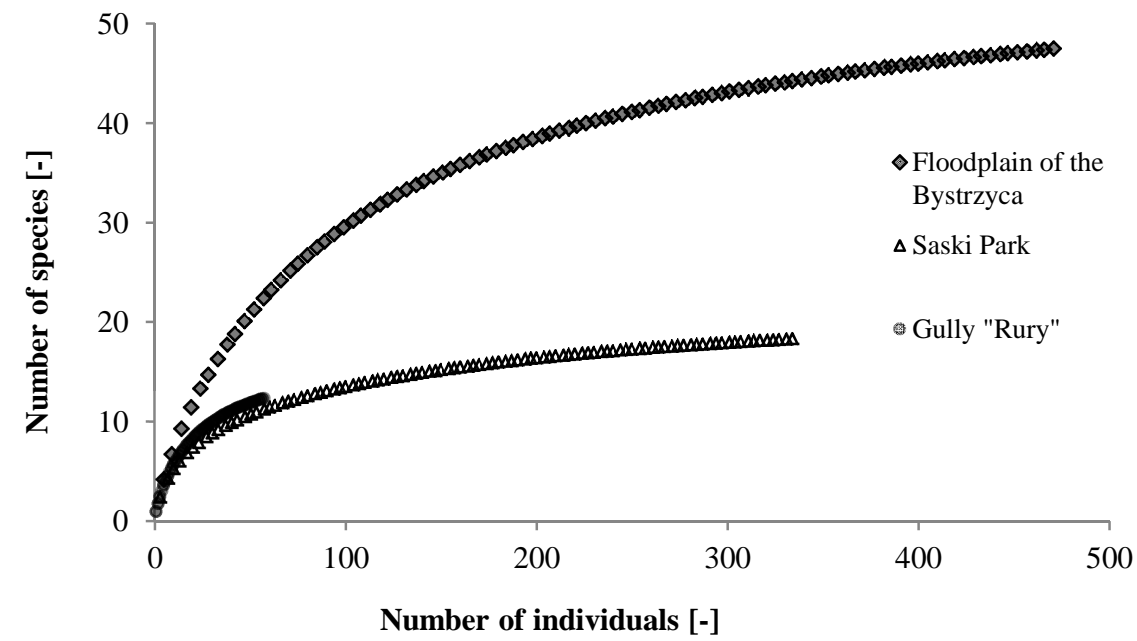

Fig. 2. Rarefaction curves for carabid beetle assemblages from the each urban green area of Lublin 
Table 2

The list of carabid species collected in the green areas of the city of Lublin; their habitat affinity (f - forest species, $\mathrm{g}$ - generalist, o - open habitat species, $\mathrm{r}$ - riparian, $\mathrm{t}$ - tyrphobiont) and dispersal ability (b - brachypterous species, $\mathrm{m}$ - macropterous, $\mathrm{d}$ - polymorphic); $\left(^{*}\right)$ - protected species

\begin{tabular}{|c|c|c|c|c|c|}
\hline \multirow[b]{2}{*}{ Species } & \multirow[b]{2}{*}{$\begin{array}{l}\text { Habitat } \\
\text { affinity }\end{array}$} & \multirow{2}{*}{$\begin{array}{c}\text { Dispersal } \\
\text { power }\end{array}$} & \multicolumn{3}{|c|}{ Urban green area } \\
\hline & & & $\begin{array}{l}\text { Floodplain of } \\
\text { the Bystrzyca }\end{array}$ & $\begin{array}{l}\text { Saski } \\
\text { Park }\end{array}$ & $\begin{array}{l}\text { Gully } \\
\text { "Rury" }\end{array}$ \\
\hline Acupalpus meridianus L., 1767 & $\mathrm{~g}$ & $\mathrm{~m}$ & $\mathrm{x}$ & - & - \\
\hline Anchomenus dorsalis Pont., 1763 & $\mathrm{o}$ & $\mathrm{m}$ & $\mathrm{x}$ & $\mathrm{x}$ & $\mathrm{x}$ \\
\hline Agonum fuliginosus Panz., 1809 & $\mathrm{f}$ & $\mathrm{d}$ & $\mathrm{x}$ & - & - \\
\hline Agonum marginatum L., 1758 & $\mathrm{r}$ & $\mathrm{m}$ & $\mathrm{x}$ & - & - \\
\hline Agonum versutum Sturm, 1824 & $\mathrm{r}$ & $\mathrm{m}$ & $\mathrm{x}$ & - & - \\
\hline Agonum viduum Panz., 1797 & $\mathrm{r}$ & $\mathrm{m}$ & $\mathrm{x}$ & - & - \\
\hline Amara aenea Deg., 1774 & $\mathrm{~g}$ & $\mathrm{~m}$ & $\mathrm{x}$ & - & - \\
\hline Amara communis Panz., 1797 & $\mathrm{O}$ & $\mathrm{m}$ & $\mathrm{x}$ & - & - \\
\hline Amara familiaris Duft., 1812 & $\mathrm{~g}$ & $\mathrm{~m}$ & - & $\mathrm{x}$ & - \\
\hline Amara littorea Thoms., 1859 & $\mathrm{O}$ & $\mathrm{m}$ & - & $\mathrm{x}$ & - \\
\hline Amara nitida Sturm, 1825 & $\mathrm{O}$ & $\mathrm{m}$ & $\mathrm{x}$ & - & $\mathrm{x}$ \\
\hline Amara plebeja Gyll., 1810 & $\mathrm{~g}$ & $\mathrm{~m}$ & $\mathrm{x}$ & - & - \\
\hline Amara similata Gyll., 1810 & o & $\mathrm{m}$ & $\mathrm{x}$ & - & - \\
\hline Amara tibialis Payk., 1798 & o & $\mathrm{m}$ & $\mathrm{x}$ & - & - \\
\hline Anisodactylus binotatus F., 1792 & $\mathrm{~g}$ & $\mathrm{~m}$ & $\mathrm{x}$ & - & - \\
\hline Anisodactylus signatus Panz., 1797 & o & $\mathrm{m}$ & $\mathrm{x}$ & - & - \\
\hline Asaphidion flavipes L., 1761 & $\mathrm{~g}$ & $\mathrm{~m}$ & $\mathrm{x}$ & $\mathrm{x}$ & $\mathrm{x}$ \\
\hline Badister dorsiger Duft., $1812^{*}$ & $\mathrm{t}$ & $\mathrm{m}$ & $\mathrm{x}$ & - & - \\
\hline Badister unipustulatus Bon., 1813 & $\mathrm{f}$ & $\mathrm{m}$ & - & $\mathrm{x}$ & $\mathrm{x}$ \\
\hline Bembidion articulatum Panz., 1796 & $\mathrm{r}$ & $\mathrm{m}$ & $\mathrm{x}$ & - & - \\
\hline Bembidion dentellum Thunb., 1787 & $\mathrm{r}$ & $\mathrm{m}$ & $\mathrm{x}$ & - & - \\
\hline Bembidion doris Panz., 1797 & $\mathrm{r}$ & $\mathrm{m}$ & $\mathrm{x}$ & - & - \\
\hline Bembidion lampros Hrbst., 1784 & $\mathrm{~g}$ & $\mathrm{~d}$ & $\mathrm{x}$ & $\mathrm{x}$ & - \\
\hline Bembidion properans Steph., 1828 & $\mathrm{O}$ & $\mathrm{d}$ & $\mathrm{x}$ & $\mathrm{x}$ & - \\
\hline Bembidion quadrimaculatum L., 1761 & o & $\mathrm{m}$ & $\mathrm{x}$ & - & - \\
\hline Bembidion quadripustulatum Aud.-Serv., 1821 & $\mathrm{t}$ & $\mathrm{m}$ & $\mathrm{x}$ & - & - \\
\hline Bembidion semipunctatum Don., 1806 & $\mathrm{r}$ & $\mathrm{m}$ & $\mathrm{x}$ & - & - \\
\hline Bembidion tetracolum Say, 1823 & $\mathrm{~g}$ & $\mathrm{~d}$ & $\mathrm{x}$ & - & - \\
\hline Bembidion varium Ol., 1795 & $\mathrm{r}$ & $\mathrm{m}$ & $\mathrm{x}$ & - & - \\
\hline Calathus erratus Sahlb., 1827 & $\mathrm{~g}$ & $\mathrm{~d}$ & - & $\mathrm{x}$ & - \\
\hline Calathus mollis Marsh., 1802 & $\mathrm{~g}$ & $\mathrm{~d}$ & - & - & $\mathrm{x}$ \\
\hline Carabus granulatus L., $1758^{*}$ & $\mathrm{~g}$ & $\mathrm{~d}$ & $\mathrm{x}$ & - & - \\
\hline Carabus nemoralis Mull., $1764^{*}$ & $\mathrm{f}$ & $\mathrm{b}$ & $\mathrm{x}$ & $\mathrm{x}$ & - \\
\hline Chlaenius nigricornis F., 1787 & $\mathrm{r}$ & $\mathrm{m}$ & $\mathrm{x}$ & - & - \\
\hline Chlaenius nitidulus Schrnk., 1781 & $\mathrm{r}$ & $\mathrm{m}$ & $\mathrm{x}$ & - & - \\
\hline Clivina collaris Hbst., 1784 & $\mathrm{~g}$ & $\mathrm{~m}$ & $\mathrm{x}$ & - & - \\
\hline Clivina fossor L., 1758 & $\mathrm{~g}$ & d & $\mathrm{x}$ & - & - \\
\hline Dyschirius aeneus Dej., 1825 & $\mathrm{r}$ & $\mathrm{m}$ & $\mathrm{x}$ & - & - \\
\hline Dyschirius tristis Steph., 1828 & $\mathrm{r}$ & $\mathrm{m}$ & $\mathrm{x}$ & - & - \\
\hline Elaphrus riparius L., 1758 & $\mathrm{r}$ & $\mathrm{m}$ & $\mathrm{x}$ & - & - \\
\hline Harpalus latus L., 1758 & $\mathrm{~g}$ & $\mathrm{~m}$ & $\mathrm{x}$ & $\mathrm{x}$ & $\mathrm{x}$ \\
\hline Harpalus luteicornis Duft., 1812 & o & $\mathrm{m}$ & $\mathrm{x}$ & $\mathrm{x}$ & $\mathrm{x}$ \\
\hline Harpalus progrediens Schaub., 1922 & $\mathrm{~g}$ & $\mathrm{~d}$ & - & - & $\mathrm{x}$ \\
\hline Harpalus xanthopus winkleri Schaub., 1922 & o & $\mathrm{m}$ & - & - & $\mathrm{x}$ \\
\hline Leistus rufomarginatus Duft., 1812 & $\mathrm{f}$ & $\mathrm{d}$ & - & $\mathrm{x}$ & $\mathrm{x}$ \\
\hline Loricera pilicornis $\mathrm{F} ., 1775$ & $\mathrm{~g}$ & $\mathrm{~m}$ & $\mathrm{x}$ & $\mathrm{x}$ & - \\
\hline Microlestes maurus Sturm, 1827 & $\mathrm{O}$ & $\mathrm{d}$ & - & $\mathrm{x}$ & - \\
\hline Nebria brevicollis F., 1792 & $\mathrm{f}$ & $\mathrm{m}$ & $\mathrm{x}$ & $\mathrm{x}$ & $\mathrm{x}$ \\
\hline
\end{tabular}




\begin{tabular}{|c|c|c|c|c|c|}
\hline Notiophilus palustris Duft., 1812 & $\mathrm{~g}$ & $\mathrm{~d}$ & $\mathrm{x}$ & $\mathrm{x}$ & - \\
\hline Oodes helopioides F., $1792^{*}$ & $\mathrm{r}$ & $\mathrm{m}$ & $\mathrm{X}$ & - & - \\
\hline Patrobus atrorufus Strom, 1768 & $\mathrm{f}$ & $\mathrm{b}$ & $\mathrm{x}$ & - & - \\
\hline Platynus assimilis Payk., 1790 & $\mathrm{f}$ & $\mathrm{m}$ & $\mathrm{x}$ & $\mathrm{x}$ & - \\
\hline Poecilus cupreus L., 1758 & $\mathrm{~g}$ & $\mathrm{~m}$ & $\mathrm{x}$ & - & $\mathrm{x}$ \\
\hline Poecilus lepidus Leske, 1785 & $\mathrm{~g}$ & $\mathrm{~d}$ & - & $\mathrm{x}$ & - \\
\hline Poecilus versicolor Sturm, 1824 & $\mathrm{~g}$ & $\mathrm{~m}$ & $\mathrm{X}$ & - & $\mathrm{X}$ \\
\hline Pseudoophonus rufipes Deg., 1774 & o & $\mathrm{m}$ & $\mathrm{x}$ & $\mathrm{x}$ & - \\
\hline Pterostichus anthracinus Ill., 1798 & $\mathrm{f}$ & $\mathrm{d}$ & $\mathrm{x}$ & - & - \\
\hline Pterostichus melanarius Ill., 1798 & $\mathrm{~g}$ & $\mathrm{~d}$ & $\mathrm{x}$ & $\mathrm{x}$ & $\mathrm{x}$ \\
\hline Pterostichus nigrita F., 1792 & $\mathrm{~g}$ & $\mathrm{~m}$ & $\mathrm{x}$ & - & - \\
\hline Pterostichus oblongopunctatus F., 1787 & $\mathrm{f}$ & $\mathrm{m}$ & $\mathrm{x}$ & - & - \\
\hline Pterostichus strenuus Panz., 1797 & $\mathrm{f}$ & $\mathrm{d}$ & $\mathrm{x}$ & - & - \\
\hline Pterostichus vernalis Panz., 1796 & $\mathrm{~g}$ & $\mathrm{~d}$ & $\mathrm{x}$ & - & $\mathrm{x}$ \\
\hline Stenolophus mixtus Hrbst., 1784 & $\mathrm{r}$ & $\mathrm{h}$ & $\mathrm{x}$ & - & - \\
\hline Stomis pumicatus Panz., 1796 & $\mathrm{f}$ & $\mathrm{b}$ & - & $\mathrm{x}$ & - \\
\hline Trechoblemus micros Hrbst., 1784 & $\mathrm{~g}$ & $\mathrm{~m}$ & $\mathrm{x}$ & - & - \\
\hline
\end{tabular}

As the urbanization (habitat fragmentation and isolation) affects the diversity of ground beetles assemblages, we compared these green areas (based on Sorensen's index of similarity). The species composition similarity between the studied green areas is low (less than 40\%): between the floodplain section of the Bystrzyca and the gully "Rury" - 29\%, between the section of the Bystrzyca and park - 35\%, between park and of the gully "Rury" - 39\%. The observed low degree of similarity between these territories is determined by the spatial heterogeneity of the urban environment and by their spatial isolation. Gaublomme with co-authors [41] states that habitat fragmentation may not lead to a loss of diversity in the short time, but rather to changes in community structure; because of the increasing disturbance and high fragmentation of urban green spaces are common [15, 16].

The cluster analysis showed significant differences in the species composition of ground beetles from the studied green zones (Fig. 3). The sites of Saski Park and "Rury", which are located among residential areas, were grouped into one cluster, and the sites of floodplain of the Bystrzyca formed another cluster. One site of the Bystrzyca floodplain (B8 - overgrown with trees and shrubs) adhered to the sites of the park and the gully, which is explained by the presence of common forest species - Carabus nemoralis, Nebria brevicollis and Platynus assimilis.

Non-metric scaling ordination also shows clear differences, along ordination axis 2, between the habitats of the Bystrzyca river floodplain and two green areas (Saski Park and gully "Rury") located in the city centre (Fig. 4). The difference between them corresponds to the degree of violation of environmental conditions. The consequences of urbanization, including: reducing soil moisture, mowing lawns and trampling in the park and the gully, affected the composition of the assemblage. These changes of the environment indirectly affect the species composition of ground beetles, reducing the survival of beetles in different stages of their development. At the same time, the species composition of the assemblage at floodplain of the Bystrzyca is determined by the connection of this landscape this valley of the river. Until now, the populations of beetles have been preserved in the artificial riversides of Bystrzyca, characteristic of natural river valleys, as will be discussed below. 


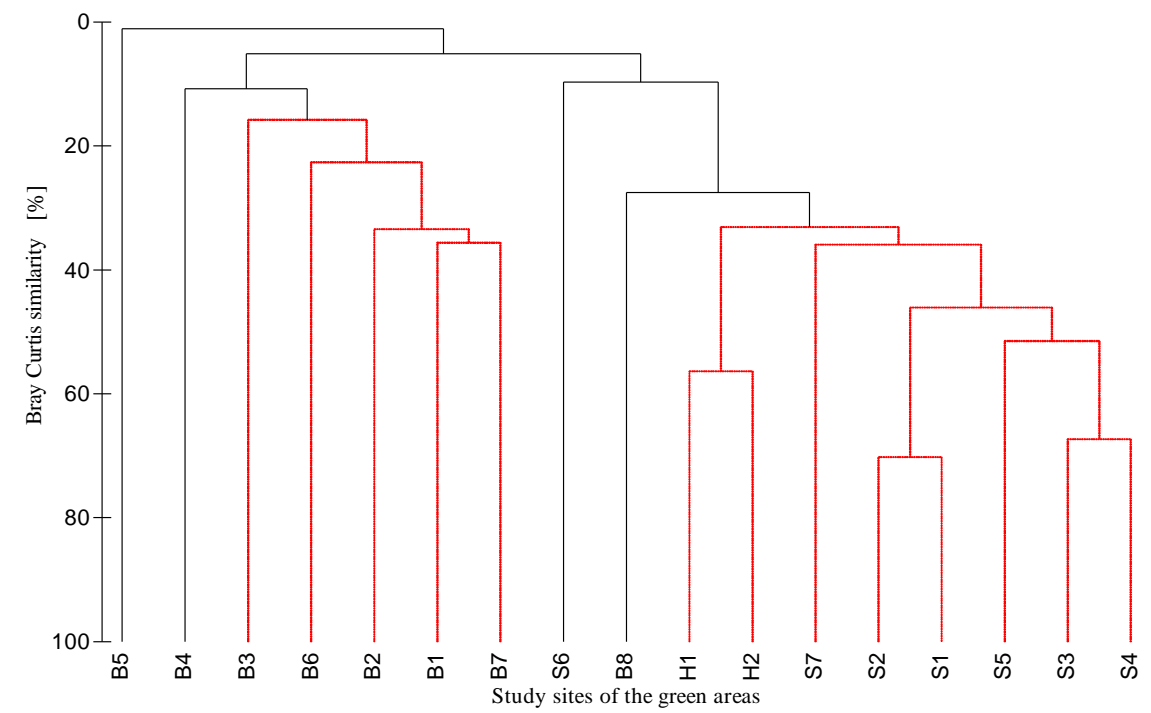

Fig. 3. Dendrogram of cluster analyses using the Bray-Curtis index as the similarity measure and the group average linkage method on the basis of the species composition in the green areas of the Lublin. The codes corresponding to study sites are presented in Table 1

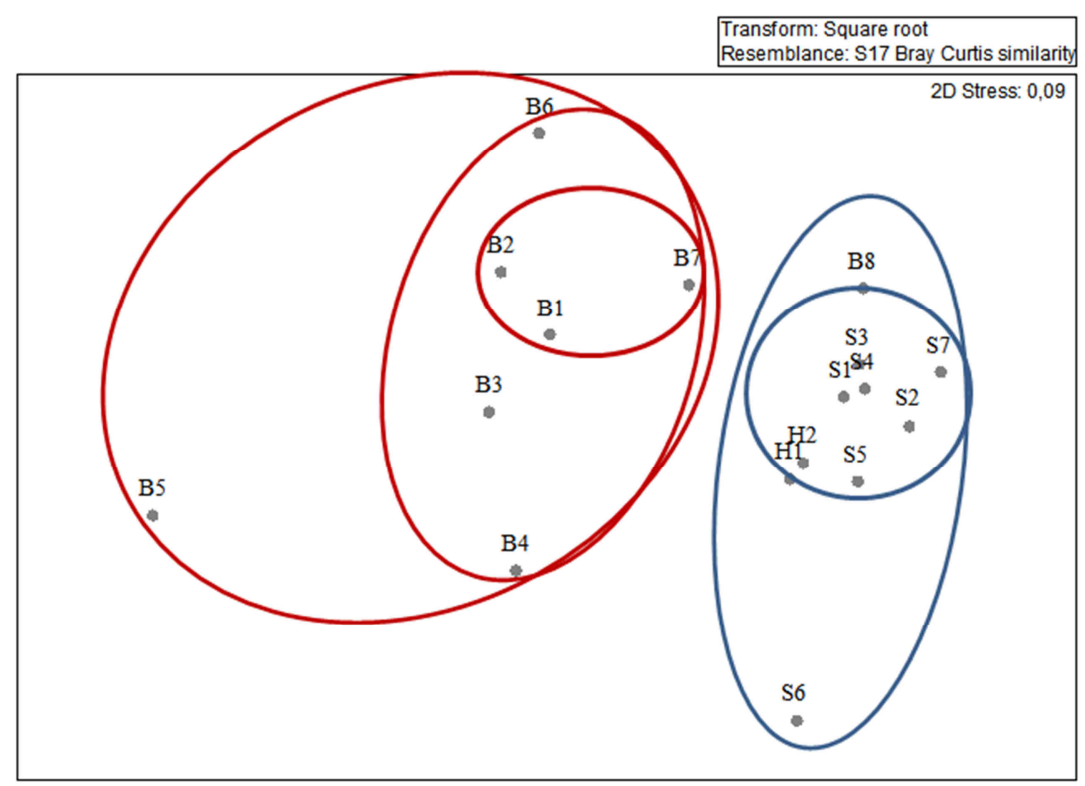

Fig. 4. Diagram NMS ordination of the sites in the green areas of the Lublin, based on 65 carabid species. For explanation of labels see Table 1

The analysis of species assemblages with respect to their traits is a known approach to the understanding of the processes observed in urban landscapes. It is obvious that urban 
environments are dominated by generalists and open-habitats species. As a consequence, the species composition of the assemblages in cities becomes homogeneous, mainly due to the loss of species specialists [42-44]. The significant alteration of the original habitats in the urban areas was also reflected by the higher number of open-habitat species which prevailed in the city centres [45].

Thus, in our study, the generalists (28\% of the total species) and open-habitat species (26\% of the total species) accounted for half of the total number of recorded carabid species in the green areas (Fig. 5a, b). At the same time, forest and generalist species were most numerous in all green areas (Fig. 5b). The carabid beetle assemblage of the floodplain of Bystrzyca is composed of five habitat affinity groups; with dominance of riparian $(28 \%)$ and open-habitat (26\%) species (Fig. 5a). As expected, representatives of riparian and tyrphobiont habitat affinity groups were recorded only in floodplain of the Bystrzyca; riparian species were the most abundant (Fig. 5b).

Three habitat affinity groups are represented in the structure of the carabid beetle assemblages of the Saski Park and the gully "Rury", with a dominance of open-habitat species (38 and 47\% respectively) (Fig. 5a). Hence, the abundant species in the Saski Park and in the gully were of forest species, while the generalists were numerous only in the gully (Fig. 5b). The prevalence of forest species may indicate that these habitats were once covered by forests. Urban habitats can contribute to the survival of species if their primary habitats are under significant pressures. The effects of urbanization lead to increase of generalist species and this is indicated by changes in assemblages.

a)

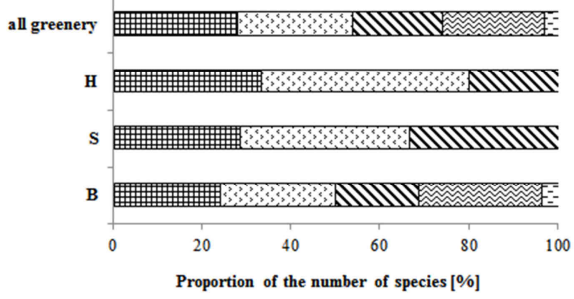

b)

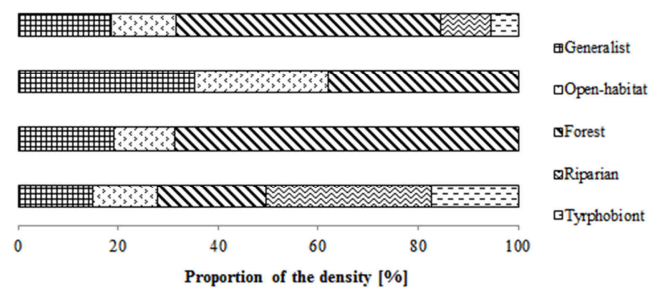

Fig. 5. The proportions of: a) number of species and b) density, according to habitat affinity groups for each green area and in all study greenery of the Lublin. Abbreviation of green areas is given in Table 1

A number of previous studies have shown that the assemblages of disturbed habitats contain more highly mobile species capable of flight [45]. High dispersal capacity of species is an important prerequisite of existence in urban environments. Our hypothesis that there would be more macropterous species in the green areas was supported. Carabid species with high dispersal ability prevailed numerically, as well as by the species richness in all studied green areas (Fig. 6a, b). The high number of flying species in the floodplain of the river Bystrzyca is understandable, because of unstable conditions and the need of searching of suitable habitats; this is why the riparian species with active dispersal ability are presented here. In carabid assemblage of the Saski Park, the macropterous (52\%) and dimorphic (38\%) species are dominant (Fig. 6a). The prevalence of macropterous species in both park and gully is caused by the conditions in unstable habitats (covering from asphalt, broken flower beds and lawns). 
a)

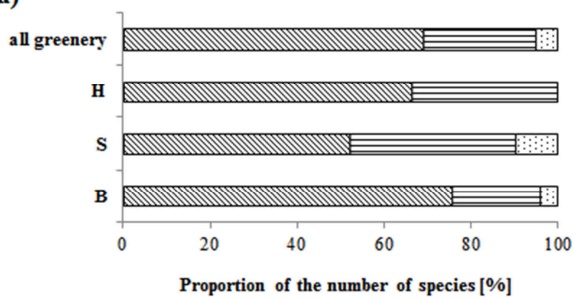

b)

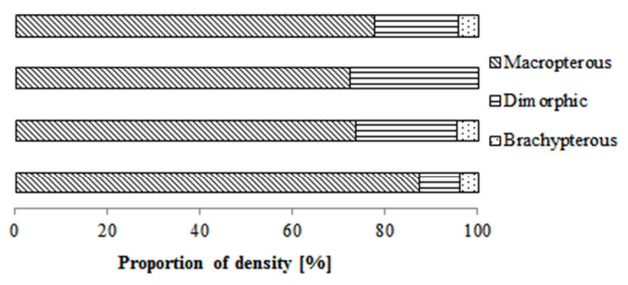

Fig. 6. The proportions of carabid species with different dispersal ability (a) and their density (b) for each green area and for all study green areas of the Lublin. Abbreviation of green areas is given in Table 1

Only three brachypterous species were found in our study and they all are forest species. Thus, C. nemoralis and Stomis pumicatus occurred in the Saski Park, Patrobus atrorufus and $C$. nemoralis were found in the sites of Bystrzyca floodplain (Table 2). This situation has been noted by other authors, stating that fewer brachypterous and many more macropterous species are present within urban areas $[16,46]$.

As analysis of beta-diversity shows (Fig. 7) the highest values of Cody and Whittaker indices were noted in valley of the Bystrzyca, as opposed to other green areas - park and gully "Rury". Hence, the values of these indices increase considerably due to the presence of green areas in Lublin (Fig. 7), which confirms the importance of conserving all existing greenery or residual natural complexes.

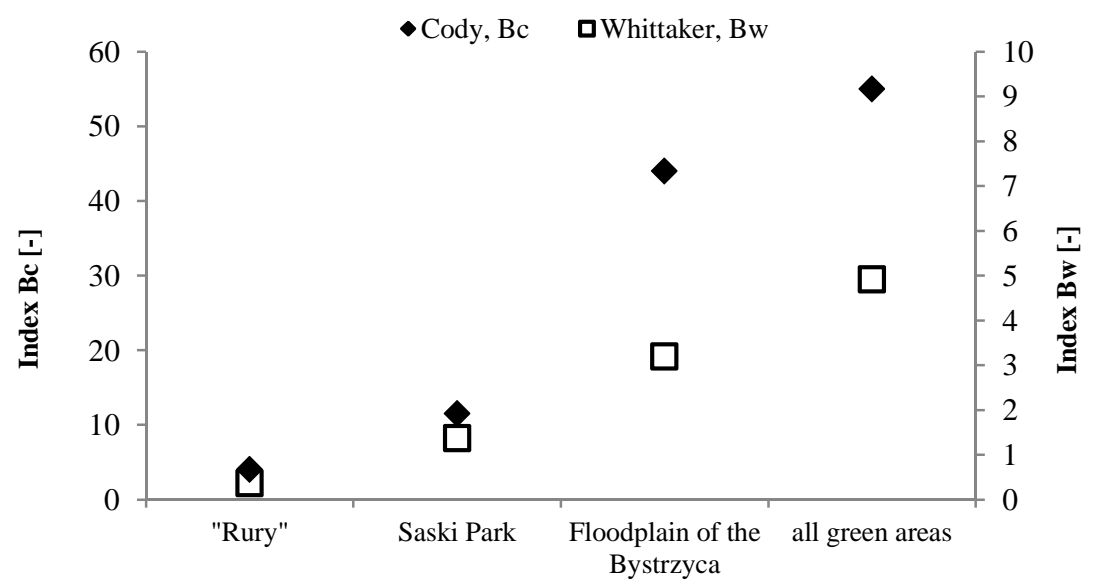

Fig. 7. Beta-diversity indices by Cody $(\mathrm{Bc})$ and Whittaker $(\mathrm{Bw})$ for each studied green area calculated separately and in total (all studied areas)

\section{Conclusions}

The various green areas in Lublin differ in terms of species richness of carabid beetles. The assemblages are limited to the isolated cultured sites (such as park with lawns and 
gully) and habitat patches along riversides of Bystrzyca. In our case, the floodplain of the river Bystrzyca (i.e. remnant of natural intrazonal landscape) is a corridor linking the green areas with the rural habitats outside the Lublin city. This is important to improve the connectivity and thus facilitate species migration and species persistence in small habitat patches of urban environment. However, the lack of connection between isolated habitats can limit their role on a landscape scale, and therefore they cannot perform the role of a refuge, especially for rare and protected invertebrate species. The presence of protected carabid species ( $C$. granulatus, $C$. nemoralis, $B$. dorsiger and $O$. helopioides) in urban sites of Lublin shows that not only the conservation of landscape elements is important for the preservation of biological diversity, but also the developments of the infrastructure of artificial green zones.

\section{References}

[1] McIntyre NE, Rango J, Fagan WF, Faeth SH. Ground arthropod community structure in a heterogeneous urban environment. Landsc Urban Planning. 2001;52:257-274. DOI: 10.1016/S0169-2046(00)00122-5.

[2] Brauniger C, Knapp S, Kuhn I, Klotz S. Testing taxonomic and landscape surrogates for biodiversity in an urban setting. Landsc. Urban Planning. 2010;97:283-295. DOI: 10.1016/j.landurbplan.2010.07.001.

[3] Olszowski T, Tomaszewska B, Góralna-Włodarczyk K. Air quality in non-industrialised area in the typical Polish countryside based on measurements of selected pollutants in immission and deposition phase. Atmos Environ. 2012;50:139-147. DOI: 10.1016/j.atmosenv.2011.12.049.

[4] Olszowski T. Comparison of $\mathrm{PM}_{10}$ washout on urban and rural areas. Ecol Chem Eng S. 2017;24(3):381-395. DOI: 10.1515/eces-2017-0025.

[5] Sims IR, Reynolds PJ. Effects of atmospheric pollution on a lichenophagous lepidopteran. Ecotoxicol Environ Safety. 1999;42:30-34. DOI: 10.1006/eesa.1998.1715.

[6] McIntyre NE. Ecology of urban arthropods: a review and a call to action. Ann Entomol Soc Am. 2000;93:825-835. DOI: 10.1603/0013-8746(2000)093[0825:EOUAAR]2.0.CO;2.

[7] Desender K, Dekoninck W, Dufrkne M, Maes D. Changes in the distribution of carabid beetles in Belgium revisited: Have we halted the diversity loss? Biol Conserv. 2010;143:1549-1557. DOI: 10.1016/j.biocon.2010.03.039.

[8] Swan CM, Pickett STA, Szlavecz K, Warren P, Willey KT. Biodiversity and community composition in urban ecosystems: Coupled human, spatial and metacommunity processes. In: Niemelä J, Breuste J, Elmqvist T, Guntenspergen G, James PP, McIntyre N, editors. Urban Ecology - Patterns, Processes, and Applications. Oxford: Oxford University Press; 2011;179-186.

[9] Kattel GR, Elkadi H, Meikle H. Developing a complementary framework for urban ecology. Urban For Urban Green. 2013;12:498-508. DOI: 10.1016/j.ufug.2013.07.005.

[10] Grandchamp A-C, Niemelä J, Kotze DJ. The effects of trampling on assemblages of ground beetles (Coleoptera: Carabidae) in urban forests in Helsinki, Finland. Urban Ecosyst. 2000;4:321-332. DOI: 10.1023/A:1015707916116.

[11] Niemelä J, Kotze DJ, Venn S, Penev L, Stoyanov I, Spence J, et al. Carabid beetles assemblages (Coleoptera, Carabidae) across urban-rural gradients: an international comparison. Landsc Ecol. 2002;17:387-401. DOI: 10.1023/A:1021270121630.

[12] Gibb H, Hochuli DF. Habitat fragmentation in an urban environment: large and small fragments support different arthropod assemblages. Biol Conserv. 2002;106:91-100. DOI:10.1016/S0006-3207(01)00232-4.

[13] Small EC, Sadler JP, Tefler MG. Carabid beetles assemblages on urban derelict sites in Birmingham, UK. J Insect Conserv. 2003;6:233-246. DOI: 10.1023/A:1024491111572.

[14] Elek Z, Lövei GL. Ground beetle (Coleoptera, Carabidae) assemblages along an urbanization gradient near Sorø, Zealand, Denmark Ent Meddr. 2005;73:115-121. https://www.researchgate.net/publication/ 230667562_Ground_beetle_Coleoptera_Carabidae_assemblages_along_an_urbanisation_gradient_near_Sor o_Zealand_Denmark.

[15] Elek Z, Lövei GL. Patterns in ground beetle (Coleoptera: Carabidae) assemblages along an urbanization gradient in Denmark. Acta Oecol. 2007;32:104-111. DOI: 10.1016/j.actao.2007.03.008.

[16] Sadler JP, Small EC, Fiszpan H, Elfer MG, Niemelä J. Investigating environmental variation and landscape characteristics of an urban-rural gradient using woodland carabid assemblages. J Biogeogr. 2006;33:1126-1138. DOI: 10.1111/j1365-2699.2006.01476.x. 
[17] Magura T, Lövei GL, Tóthmérész B. Does urbanization decrease diversity in ground beetle (Carabidae) assemblages? Global Ecol Biogeogr. 2010;19:16-26. DOI: 10.1111/j.1466-8238.2009.00499.x.

[18] Martinson HM, Raup MJ A meta-analysis of the effects of urbanization on ground beetle communities. Ecosphere. 2013;4:60. DOI: 10.1890/ES12-00262.1 (accessed 06.08.2014).

[19] Żelazna E, Błażejewicz-Zawadzińska M. Species diversity of carabids in different types of Bydgoszcz urban green belts and suburban environments. Folia Biol. 2005;53:179-186. DOI: 10.3409/173491605775789498.

[20] Żelazna E, Błażejewicz-Zawadzińska M. Zróżnicowanie gatunkowe biegaczowatych (Coleoptera: Carabidae) terenów parkowych Bydgoszczy oraz wybranych kompleksów leśnych i zadrzewień śródpolnych obszaru kujawsko-pomorskiego (Carabidae species variation (Coleoptera: Carabidae) in the parks of Bydgoszcz and selected forest complexes and midfield plantings of the Kujawy and Pomorze region). Wiad Entomol. 2006;25(1):129-140. http://pte.au.poznan.pl/we/2006/WE25_Supl_1.pdf.

[21] Sattler T, Duelli P, Obrist MK, Arlettaz R, Moretti M. Response of arthropod species richness and functional groups to urban habitat structure and management. Landsc Ecol. 2010;25:941-954. DOI: 10.1016/j.landurbplan.2011.08.008.

[22] Venn SJ, Kotze DJ, Niemelä J. Urbanization effects on carabid diversity in boreal forests. Eur J Entomol. 2003;100:73-80. DOI: 10.14411/eje.2003.015.

[23] Venn SJ, Kotze DJ, Lassila T, Niemelä J. Urban dry meadows provide valuable habitat for granivorous and xerophylic carabid beetles. J Insect Conserv. 2013. DOI: 10.1007/s10841-013-9558-8.

[24] Kirichenko M, Lagod G, Babko R. Distribution of carabid beetles (Coleoptera, Carabidae) in the urban area of Lublin. Proc of ECOpole. 2012;6(1):157-163. DOI: 10.2429/proc.2012.6(1)021.

[25] Hůrka K. Carabidae of the Czech and Slovak Republics. Zlin: Kabourek; 1996.

[26] Lindroth $\mathrm{CH}$. The Carabidae (Coleoptera) of Fennoscandia and Denmark. Leiden, Copenhagen: Scandinavian Science Press Ltd.; 1985.

[27] Lindroth $\mathrm{CH}$. The Carabidae (Coleoptera) of Fennoscandia and Denmark. Leiden, Copenhagen: Scandinavian Science Press Ltd.; 1986.

[28] Den Boer PJ. On the significance of dispersal power for populations of carabid-beetles (Coleoptera, Carabidae). Oecologia. 1970;4:1-28. DOI: 10.1007\%2FBF00390612.

[29] Homburg K, Homburg N, Schaefer F, Schuldt A, Assmann T. Carabids. Org-a dynamic online database of ground beetle species traits (Coleoptera, Carabidae). Insect Conserv Divers. 2014;7:195-205. DOI: 10.1111/icad.12045.

[30] Magurran AE. Measuring Biological Diversity. Oxford: Blackwell; 2004.

[31] Clarke KR. Non-parametric multivariate analysis of changes in community structure. Aust J Ecol. 1993;18:117-143. DOI: 10.1111/j.1442-9993.1993.tb00438.x.

[32] Clarke KR, Warwick RM. Change in marine communities: an approach to statistical analysis and interpretation, 2nd edition. Plymouth: PRIMER-E; 2001.

[33] Głowaciński Z, Nowacki J, editors. Polska czerwona księga zwierząt. Bezkręgowce. (Polish Red Data Book of Animals. Invertebrates). Poznań: IOP PAN \& AR; 2004.

[34] Hyman PS, Parsons MS. A Review of the Scarce and Threatened Coleoptera of Great Britain. Part 1. UK Nature Conservation, 3, JNCC, Peterborough. 1992; 1-484. http://jncc.defra.gov.uk/page-6404.

[35] Rote Liste gefährdeter Lauf- und Sandlaufkäfer (Coleoptera Carabidae s. 1.). (in English). Bayerns. BayLfU. 2003;166:102-111. http://www.Ifu.bayern.de/natur/rote_liste_tiere/2003/doc/tiere/carabidae.pdf.

[36] Gaublomme E, Eggermont H, Hendrickx F. Local extinction processes rather than edge effects affect ground beetle assemblages from fragmented and urbanised old beech forests. Insect Conserv Divers. 2013:1-9. DOI: 10.1111/icad.12036.

[37] Kosewska A, Nietupski M, Damszel M. Role of urban forests as a source of diversity of carabids (Coleoptera: Carabidae) in urbanized areas. Baltic J Coleopterol. 2013;13(1):27-39. http://bjc.sggw.waw.pl/arts/2013v13n1/03.pdf.

[38] Tóthmérész B, Máthé I, Balázs E, Magura T. Responses of carabid beetles to urbanization in Transylvania (Romania). Landsc Urban Planning. 2011;101:330-337. DOI: 10.1016/j.landurbplan.2011.02.038.

[39] Pétremand G, Chittaro Y, Braaker S, Brenneisen S, Gerner M, Obrist MK, et al. Ground beetle (Coleoptera: Carabidae) communities on green roofs in Switzerland: synthesis and perspectives. Urban Ecosyst. 2017. DOI: $10.1007 / \mathrm{s} 11252-017-0697-7$.

[40] Magura T, Tóthmérész B, Molnár T. Changes in carabid beetle assemblages along an urbanization gradient in the city of Debrecen, Hungary. Landsc Ecol. 2004;19:747-759. DOI: 10.1007/s10980-005-1128-4.

[41] Gaublomme E, Hendrickx F, Dhuyvetter H, Desender K. The effects of forest patch size and matrix type on changes in carabid beetle assemblages in an urbanized landscape. Biol Conserv. 2008;141:2585-2596. DOI: 10.1016/J.BIOCON.2008.07.022. 
[42] Hartley DJ, Koivula MJ, Spence JR, Pelleitier R, Ball GE. Effects of urbanization on ground beetle assemblages (Coleoptera, Carabidae) of grassland habitats in western Canada. Ecography. 2007;30:673-684. DOI: 10.1111/j.2007.0906-7590.05199.x.

[43] Niemelä J, Kotze J, Ashworth A, Brandmayr P, Desender K, New T, et al. The search for common anthropogenic impact on biodiversity: a global network. J Insect Conserv. 2000;4:3-9. DOI: 10.1023/A:1009655127440.

[44] Niemelä J, Kotze DJ. Carabid beetle assemblages along urban to rural gradients: a review. Landsc Urban Planning. 2009;92:65-71. DOI: 10.1016/j.landurbplan.2009.05.016.

[45] Gray JS. Effects of environmental stress on species rich assemblages. Biol J Linn Soc. 1989;37:19-32. DOI: 10.1111/j.1095-8312.1989.tb02003.x.

[46] Small E, Sadler JP, Telfer MG. Do landscape factors affect brownfield carabid assemblages? Sci Total Environ. 2006;360:205-222. DOI: 10.1016/j.scitotenv.2005.08.051. 